\title{
DIALING AND INVESTIGATION OF NOTARY BY INVESTIGATOR POLICE
}

\author{
Nur Aisyah \\ Notary Brebes \\ aish31398@gmail.com
}

\begin{abstract}
Relationship notary to do with legal issues consciously or notary in practice are often faced with the proceedings or deal with the authorities caused the parties to a deed in front of him, and that the dispute can be reported to the investigator. So often a notary summoned by investigators with regard to the deed he made. In terms of the calling and notary investigation by an investigator there own rules set out in the Act. Although the implementation of the functions and investigations and inquiries Act gives the right to call, check, catching, defense minister, searched, confiscated to suspects and items are considered connected with a criminal offense, but in exercising its rights and authority must be obedient and subject to the principle of the right of due process (upholding the rights of the accused in the process of law enforcement). Each suspect is entitled researched and investigated based in accordance with the applicable law of criminal procedure. The concept of due process associated with the foundation of upholding the rule of law in dealing with crime. No one is located and put themselves above the law and the law should be applied to anyone based on the principle of treatment in an honest way. The application of the criminal law should be in accordance with the constitutional requirements and must comply with the law. By karen it does not allow the violation of a part of the general provisions on the pretext in order to enforce another law section.
\end{abstract}

Keywords: Criminal; Investigator; Notary.

\section{A. INTRODUCTION}

Pancasila and the 1945 Constitution $^{1}$ is the supreme power in Indonesia. Where in the articles contained in it has been ascertained that the state has provided a guarantee for all citizens to obtain certainty, order, and legal protection that core truth and justice. Certainty, order, and the legal protection that would require concrete efforts closely held as a form of state responsibility

1 Indonesian Constitution of 1945 for the welfare of all the people of Indonesia ${ }^{2}$.

In certain areas of the task by the government through the Law given and entrusted to the Notary and vice versa community must also believe that the Deed made that provides legal certainty for citizens, in accordance with the wording of Article 15 paragraph 1 of Act No.2 of 2014 junto the Act No.30 of 2004 concerning Notary (hereinafter referred UUJN).

2 Tan Thong Kie, 1998, Study Notary and Notarial Practice Sundries, the second book, PT Ichtiar Van Hoeve 
"Notary authorized to make the authentic act on all deeds, agreements and statutes that are required by the rules and regulations and / or desired by the stakeholders to be stated in an authentic deed, guaranteeing the creation date of the deed, saving certificates, giving grosse, copy and quotes deed, all along the deed was not also be assigned or excluded to other officials or any other person specified by law.

Notary is a public official only authorized by the state in the field of civil law which is professionally competent make an authentic deed. Notary is a public official authorized to make an authentic deed as far as the manufacture of certain authentic deed is not reserved for other public officials. No authentic deed required by the legislation in order to create certainty, order, and legal protection. In addition to an authentic deed made by or in the presence of a Notary, not only because it is required by legislation ${ }^{3}$, but also as desired by the stakeholders to ensure the rights and obligations of the parties for the sake of certainty, order, and legal protection for interested parties as well as for society as a whole.

3 Soegianto, 2002, Professional Ethics and Legal Protection for Notaries, CV Farisma Indonesia
Position notary is not a position that is paid by the government, but of those who ask for services to him. Notary as a government employee who does not receive a salary from the government but run most tasks of government/ruling. In carrying out his duties and the notary must perform profesional.Notaris should be able to provide legal services to those in need of his services. Provide legal advice and explanation of laws to parties whose main bersangkutan. Wewenang notary is to make an authentic deed. A notary may only perform or execute his post in the entire area allotted to it and only in the area of law that he had the authority.

One task of the notary office is poured desire / confronts action / the confronts into the form of an authentic deed, having regard to the rule of law. Notaries in a deed in accordance with the form established by law. In creating authentic act of a notary must understand and study carefully according to what they mean and the will of confronts / the confronts by referring to the SOP in making authentic act in accordance with the wishes of the parties and is valid ${ }^{4}$. In the Supreme Court Decision No.: 702 k

4 Dr. Mulyoto, 2000, Criminalization Notary In Making The Deed, PT. Horizon Media 
/ Sip / 1973, 5 September1973 mentioned "Notary function only record / write down anything that you want and put forward by the parties facing the notary. There is no obligation for the notary to investigate any material (stuff) is expressed by the confronts before a notary public. Based on the substance of the Supreme Court ruling that if the deed made by or in the presence of the notary problem or question the parties confronts, then it is a matter for the parties themselves and the notary does not need to be involved because the notary is not a party in the deed. Notary just pour anything that the parties want. There notary duties only framing and formulating the will of the parties in the form of the authentic act in accordance with applicable laws. Based on the substance of the Supreme Court ruling that if the deed made by or in the presence of the notary problem or question the parties confronts, then it is a matter for the parties themselves and the notary does not need to be involved because the notary is not a party in the deed. Notary just pour anything that the parties want ${ }^{5}$. There notary duties only framing and formulating the will of the parties in

5 Dr. Habib Adjie, SH, M. Hum, 2013, Legal Notary Indonesia, PT Refika Aditama the form of the authentic act in accordance with applicable laws. Based on the substance of the Supreme Court ruling that if the deed made by or in the presence of the notary problem or question the parties confronts, then it is a matter for the parties themselves and the notary does not need to be involved because the notary is not a party in the deed. Notary just pour anything that the parties want. There notary duties only framing and formulating the will of the parties in the form of the authentic act in accordance with applicable laws ${ }^{6}$.

Authentic deeds as proof of the strongest and most have an important role in any legal relations in society. In a variety of business relationships, activities in the fields of banking, land, social activities, and others, the need for proof in writing in the form of an authentic deed is increasing in line with increasing demand for legal certainty in a variety of economic and social relations, both at the national, regional, and globally. Through authentic act that clearly defines the rights and obligations, ensure legal certainty, and at the same time is also expected to avoid disputes. Although

6 GHS Lumban Tobing, SH, Notary Regulations, PT. Primary Literacy Gelora 
the dispute can not be avoided, in the dispute settlement process ${ }^{7}$.

Authentic act essentially contains formal correctness notified in accordance with what the parties to the Notary. However, a notary has a duty to enter that what is contained in the Deed truly understood and in accordance with the will of the parties, that is the way to read it so that it becomes clear the contents Deed, as well as provide access to information, including access to legislation related to the parties signatory to the deed. Thus, the parties may determine to be free to agree or not menyetujuiisi Deed to be signed ${ }^{8}$.

Deed made by the notary is authentic act which has permanent legal force. According to Article 1868 of the Civil Code to authenticate the deed it must meet the following requirements:

1. It shall be made by the (door) or presence (tenoverstaan) a public official.

2. It shall be made in the form prescribed by law.

7 Amirudin and Zainal Asikin, Introduction Methods Legal Research Is Conducted, Jakarta: Raja Grafindo Persada

8 P. Joko Subagyo, Methods in Theory and Practice, Jakarta: PT Rineka
3. Public officials by/or before whom the deed was made, should have the authority to make the deed. ${ }^{9}$

The authentic act is definitely a criminal offense if it is made in accordance with the law applicable shrimp. The legal certainty in addition to the authenticity of a certificate that has the strength of evidence, ie outwardly, formal and material as well as the ethics of a Notary Public in the running position. In carrying out his duties of the Notary not only carry out the work mandated by legislation alone as well as running a very important social function that is responsible for carrying out the trust given it serves the general public, a Notary must cling to the Notary Code.

The scope of this Code set out in Chapter II, Section 2 of the Code of Notaries that where its scope covers all members of the Association and others who assume and execute well in implementing the Notary office and the office of everyday life. Based on the article can be concluded that this Code govern the behavior of members of the Association and others who assumed his position as a Notary and run well

9 GHS. Lumban Tobing S.H, Notary Regulation, Erlangga, Jakarta, p. 48. 
when running the office as well as in their daily lives. ${ }^{10}$

As a profession that meets the needs of society and be responsible in their services, Notary profession have an oath of office that must be adhered to. The oath or affirmation shall be pronounced by a Notary according to his belief that done in front of the Minister or the official.

If the oath is described, there are several things that should by a Notary in accordance with his promise, namely:

1. Obedient and faithful to the Republic of Indonesia, Pancasila and UUD 1945, Law on Notary, etc.

2. Running with the Notary office as trustworthy, honest, thorough, independent and impartial.

3. Keeping attitudes and behavior.

4. Responsibility as a Notary in accordance with the profession ethic, honor, dignity.

5. Conceal the contents of the deed and description

6. Do not give or promise anything to anybody. ${ }^{1}$

In terms of supervision of the notary had formed a body which has the authority and obligation to

10https://adityoariwibowo.wordpress.com/2013/0 4/17/sekilas-tentang-kode-etik-notaris, accessed on 15 November 2017 at 10:15
Develope and Supervision of the Notary. Supervision over Notary made by the Minister in this case is the Minister of Justice and Human Rights of the Republic of Indonesia to establish the Supervisory Council divided over Central Supervisory Council, the Supervisory Council of Regional and Local Supervisory Council. ${ }^{2}$ Each of the Supervisory Council has the duty and authority of its own, and gradually Regional Supervisory Council is responsible for its performance to the Supervisory Council Supervisory Council of Territory Territory then be responsible for its performance to the Supervisory Council and Assembly Center Supervisor The center is responsible for its performance to the Minister of Justice and Human Rights of the Republic of Indonesia.

Assembly Supervisor notaries who formed the Ministry of Justice and Human Rights of the Republic of Indonesia as the executor of guidance and supervision of Notary must be maximal in performing supervisory duties also in giving a warning to the Notary who commits an offense by providing strict sanctions by using Guidelines Task Panel of Trustees Notary stipulated in Decree Law and 
Human Rights of the Republic of Indonesia No. M.39-PW.07.10 2004.

To protect the public interest and ensure the implementation of the notary office entrusted by law and society in general, the existence of legal arrangements regarding monitoring the implementation of the notary office is very appropriate, because in the running position of a notary is not only running the office mandated by the enactment legislation, but also serves as a servant of the law covering a very wide field. With the code of conduct, which served the public interest would be guaranteed that further strengthen public confidence.

Inspection and sanctions in the first instance be implemented by the new Regional Honor Council will determine whether or not the decision of the proven code violations and sanctions against violators, after hearing testimony and defense of purpose. When the ruling council area proved their honor code violations, the assembly once "decisive sanctions" against violators. (Article 9, paragraph $5)$.

Regional Supervisory Council have special powers that were not owned by the Regional Supervisory
Council and the Supervisory Council of the Center. Sanctions reprimand and a warning by the WCA Board area is not obliged to consult in advance crimped Board The terrain, but the sanction of suspension (schorsing) or dismissal (onzetting) Adri membership decised advance with the caretaker Quintessentially (Paragraph 9, paragraph (8). Inspection and sanctions on appeal implemented by the Regional Ethics Council (Article 10). Decisions which contain sanctions of dismissal while (schorsing) or dismissal (onzetting) from association membership can be submitted / filed an appeal to the Regional Ethics Board.

If the checks and sanctions in the first level has been carried out by the Regional Ethics Council, since the level of the management of the areas concerned have not established the Honorary Board of the Regions, the decision of the Council of Honor The area is a decision the appellate level.

Imposition of a witness on the last level carried out by the Honorary Board of the Center. Decisions which contain sanctions of dismissal while (schorsing) or dismissal (onzetting) of a membership association made by the WCA Board requested inspection area can be submitted on the last level to 
the Honorary Board of the Center. Execution of sanctions in violation of the code of conduct based on the decision set by the board of the Regional Honor, Honorary council established by the Regional and Central Honorary Board implemented by the Regional Committee.

In the case of a notary public or participating allegedly committed a crime then the Notary Act already provides a special mechanism. When a notary will be called by investigator, then it must be done in accordance with what has been stipulated in the Law on the Notary.

Article 66 of Law Notary is very clear calling and taking minutes of the deed by the investigator.

Article 66 of Act No.2 of 2014 concerning Notary

(1) For the purposes of judicial proceedings, investigators, prosecutors or judges with the approval of the competent notary honorary board assembly:

a. Take a photocopy minuta deed and / or letters attached to Minuta Deed or the Protocol Notary Notaries in storage; and;

b. Calling the notary to be present in the examination relating to the Deed or protocols that are in storage Notary Public Notary.

(2) Minuta Deed or making photocopies of the letters referred to in paragraph (1) letter a, made news handover.

(3) Notary Honorary Council within a period of 30 (thirty) harikerja after the receipt of the letter a request for approval as referred to in (1) must provide answers to accept or reject the request for approval.

(4) In the case of assemblies honor Notary not provide an answer within the period referred to in paragraph (3), honor assemblies Notary deemed to accept the request for approval.

\section{B. DISCUSSION}

Act Number 30 of 2004 concerning Notary does not contain penal provisions for notaries. But that does not mean notary impunity when committing an offense in the running position. In general offenses opportunity and often related notary office of which is the falsification of documents or letters (articles 263 and 264 of the Criminal Code), embezzlement (Article 372 and 374 of the Criminal Code, money laundering, and false information (Article 242 of the Criminal Code). 
In the crime of falsification of documents or letters, cases that do notary of which is the act of forgery customs deposit (SSB) acquisition of land and buildings (BPHTB) and tax collection letter (SSP).

Further criminal acts that likely occurred in the notary is "embezzlement," for example embezzlement fees for acquisition of land and buildings (BPHTB) paid clients. Other possible criminal acts involved criminal notary is "money laundering" as stated in Act No.8 of 2010 on the Prevention and Combating of Money Laundering. The modus operandi is, the owner of the money to buy shares which are then recorded in a notarial deed. Stock purchase mode facilitates money launderers to move money. If the form of shares, the proceeds of crime automatically becomes valid so easily moved as desire offender. Therefore notaries as a profession tasked to make certificate of incorporation and sale of shares are required to be aware of the possibility of money laundering.

Meanwhile other offenses that may be performed notary is giving false testimony under oath as referred to in Article 242 KUHP.Dalam efforts of law enforcement in criminal offenses above, simultaneously on May 9, 2006, the National Police and the Indonesian Notary Association (INI) and Land Deed official ties (IPPAT) signed a memorandum of understanding. THIS between the National Police and the forth in a memorandum of understanding deed No. Pol. B / 1065 / V / 2006 and No. 01 / MOU / PP-INI / V / 2006 on the Development and Improvement of Professionalism in law. Even with IPPAT Enforcement, Police held a memorandum that stated in the deed No. 05 / PP-IPPAT / V / 2006 on the Development and Improvement of Professionalism in Law Enforcement.

Based on the memorandum of understanding in principle legal action by investigators such as calling, examination, seizure and other actions by law responsible according to article 7, paragraph (1) letter J Criminal Procedure Code can also be made to the notary or PPAT in accordance with article 66 UUJN.

In the case of investigators to conduct examination of a notary or PPAT related to the existence of a crime of "right of refusal" / "right to refuse" the notary or PPAT can be removed in the interest of the law or 
public interest more valuable than personal interest relating to the content of the deed or by their general rules provide an exception as defined in article 4 (2), article 16, paragraph (1) letter e and article 54 UUJN. In other that, in the case of the alleged crime, the investigator action against the notary deed / PPAT and or protocols are in storage notary or PPAT to prove criminal case and / or the involvement of a notary or PPAT as a suspect then the investigator must consider the procedure as stipulated in article 66 UUJN as well as the Supreme Court Directive No. MA / Preamb./ 3429/86 dated 12 April 1986.

Definition of Investigation according to the Criminal Code, investigation is a series of actions the investigator in the case and in the manner set forth in this Act to search for and collect evidence with evidence that makes the light or clear about the crime that happened and to find the suspects.

In the Criminal Code provisions above, explains that the meaning of Investigation is every act of investigators to find evidence that would convince or support the belief that criminal acts or acts that are prohibited by the penal provisions that actually have occurred. Collecting material such information to support the belief that a crime has actually occurred, should be done by considering the shared meaning of the willingness of law which in fact, whether the act or event penal (criminal) is contrary to the values that live in the community in the local community.

Investigations conducted by law enforcement officials that the state police to locate and uncover information or information about events that allegedly carried out by someone who is not known the identity of the culprit. Information or even information that could explain the events that allegedly carried out by someone who is not known the identity of the culprit. Information or even information that could explain the events that allegedly constitute a criminal incident (criminal).

In an act of violation committed by a profesinotaris there are some matters covered therein, among others, violations of the code of conduct, malfeasance, and if there are criminal elements. If in a Notarial acts committed happen kerugianyang Notary deed due out tasks / or 
position, such as fraud or embezzlement misalnyaterdapat element, then this action can dilaporkanlangsung to the police for further action as the occurrence of illegal acts that have been regulated in the Law Legal criminal.

\section{CONCLUSION}

Notary as a public official authorized to make an authentic deed must be accountable for the deed he had made if it turns out later raised the issue of an authentic deed. Problems arising from notarial deed made questionable, whether as a result of the notary error or mistake of the parties did not provide information and documents required honestly. If the error occurs in the manufacture of tersebutberasal authentic act of the parties to a legal act by giving information dishonest and documents complete tidk / hidden by the parties, an authentic deed made the flawed law notary, and when because the statements of the parties are dishonest or hiding something important document that should be shown to the notary public, the parties to the legal actions may be subject to criminal prosecution by other parties who feel aggrieved by the making of the authentic deed.
Criminal laws that can be used to conduct criminal prosecutions against those parties is Article 266 paragraph (1) of the Penal Code which states: "Whoever ordered included false information regarding a right in an authentic deed that the truth must be stated by deed with intent for using or to get someone else to use it as if the statement is in accordance with the truth, shall be imprisoned forever seven years if its use can result in losses. Notary makes authentic act referred to above even though he was not involved in the falsification of information in an authentic deed can only be done by the national police investigators in his capacity as a witness in the matter. When in the investigation and the police investigation turns obtained sufficient preliminary evidence on the involvement of notaries in entering false information in an authentic deed he made, then it is possible that the notary can be used as a suspect. For starters sufficient evidence of the national police investigators to use article 266 paragraph (1) of the Criminal Code, among others: Notary makes authentic act referred to above even though he was not involved in the falsification of information in an 
authentic deed can only be done by the national police investigators in his capacity as a witness in the matter. When in the investigation and the police investigation turns obtained sufficient preliminary evidence on the involvement of notaries in entering false information in an authentic deed he made, then it is possible that the notary can be used as a suspect. For starters sufficient evidence of the national police investigators to use article 266 paragraph (1) of the Criminal Code, among others: Notary makes authentic act referred to above even though he was not involved in the falsification of information in an authentic deed can only be done by the national police investigators in his capacity as a witness in the matter. When in the investigation and the police investigation turns obtained sufficient preliminary evidence on the involvement of notaries in entering false information in an authentic deed he made, then it is possible that the notary can be used as a suspect. For starters sufficient evidence of the national police investigators to use article 266 paragraph (1) of the Criminal Code, among others: When in the investigation and the police investigation turns obtained sufficient preliminary evidence on the involvement of notaries in entering false information in an authentic deed he made, then it is possible that the notary can be used as a suspect. For starters sufficient evidence of the national police investigators to use article 266 paragraph (1) of the Criminal Code, among others: When in the investigation and the police investigation turns obtained sufficient preliminary evidence on the involvement of notaries in entering false information in an authentic deed he made, then it is possible that the notary can be used as a suspect. For starters sufficient evidence of the national police investigators to use article 266 paragraph (1) of the Criminal Code, among others: Knowingly or intentionally submit false information to the authentic deed that made sehingg menguntungkn themselves and / or those who enter false information itukedalam the authentic act and meruikan others. And due to negligence or carelessness that makes the entry of fake information into an authentic deed made.

Both of the above points are used as the basis of the national police investigating a crime that resulted in a 
notary can be called up by the national police investigators that each stands alone and is not a cumulative requirement. Knowingly or intentionally submit false information in an authentic AKAT a criminal act called dolus (intent). Meanwhile, because of negligence or of the carelessness that makes the inclusion of false information in an authentic deed is a crime called culpa (negligence).

In summoning and examination conducted by the investigator to the national police notary must fulfill the legal procedures in accordance with applicable laws and undanganyang in summoning and notaries as public officials with regard to violations of the law committed in office.

In Act No. 4 of knowledge in 2004 calling procedures, notary examination by the national police investigators and for the benefit of the judicial process set out in Article 66.

For the purposes of judicial proceedings, investigators, prosecutors or judges with the approval of the competent regional supervisory council: Take a photocopy minuta deed and / or letters attached to Minuta Deed or the Protocol Notary Notaries in storage; and Calling the notary to be present in the examination relating to the Deed or protocols that are in storage Notary Public Notary; Minuta Deed or making photocopies of the letters referred to in paragraph (1) letter a, made news handover. 


\section{BIBLIOGRAPHY}

\section{Books:}

Amirudin and Zainal Asikin, Introduction Methods Legal Research Is Conducted, Jakarta: Raja Grafindo Persada

Dr. Habib Adjie, SH, M. Hum, 2013, Legal Notary Indonesia, PT Refika Aditama

Dr. Mulyoto, 2000, Criminalization Notary In Making The Deed, PT. Horizon Media

GHS Lumban Tobing, SH, Notary Regulations, PT. Primary Literacy Gelora

P. Joko Subagyo, Methods in Theory and Practice, Jakarta: PT Rineka

Soegianto, 2002, Professional Ethics and Legal Protection for Notaries, CV Farisma Indonesia

Tan Thong Kie, 1998, Study Notary and Notarial Practice Sundries, the second book, PT Ichtiar Van Hoeve

Indonesian Constitution of 1945

Act Number 30 of 2004 jo Act Number 2 of 2015

The Code of Criminal

The Book of Criminal Law 